\title{
STEM Career Aspirations of Emirati Youth
}

\author{
Prof. Sufian A. Forawi
}

\begin{abstract}
Scientific, engineering and technological advancements, in developed countries, greatly impact their environmental, social and economic priorities. STEM education is considered one of these priorities that is recently emerged as a direct reflection of such scientific progression. The main purpose of this study was to investigate Emirati youth's STEM career aspirations and their demographic variables. Factor-analy tic procedures revealed a robust three-factor structure that contributed to the development of three research questions for the study. Findings are presented in different tables to indicate main STEM related career and gender influence as identified by participating youth. Discussion, recommendations and conclusion are also presented.
\end{abstract}

Index Terms-Career Aspirations, STEM Careers, STEM Education.

\section{INTRODUCTION}

Scientific, engineering and technological advancements, in developed countries, greatly impact their environmental, social and economic priorities. STEM education is considered one of these priorities that is recently emerged as a direct reflection of such scientific progression. A successfulcareer can be a source of self-esteem, fulfillment, and adds meaning to life. From a theoretical frame of reference, career achievement often serves as a societal measure of an individual's quality of life and position in society [1] [2] [3]. Researchers have shown that future career success can be predicted as early as adolescence [4] [5] [6]. A range of factors, such as socioeconomic background, ability, grades, social behavioral style, and self-efficacy were found to predict future career success. Social cognitive career theory seems to effectively explain why young people are motivated to pursue certain tasks or jobs. This is also influenced by self-determination or self-efficacy theory and its influence over career-decision making, and student's future career aspirations and career choices. Self-efficacy refers to the beliefs people have about their ability to successfully complete the steps required for a given task [7] [8].

The start of the new millennium has witnes sed great scientific advancements that impact every division of people's social and economic foundations. STEM education is considered one of these priorities that is recently emerged as a direct reflection of such scientific growth [9]. STEM occupations are identified in a variety of ways. This article uses a list based on the Standard Occupational Classification Manual (SOCM) [10]. to analyze occupations from six groups, including computer and mathematics; architecture and engineering; and life, physical, and social sciences. Some rewards for STEM careers include feeling respected and fulfilled. Yet, there are some challenges that prospect STEM experts and workers may face, such as, that those prospective need to have a combination of skills, education, and experience, funding issues, juggling different [priorities between owners and contactors, and keeping projects on schedule.

Science educators stress the importance of a cumulative interdisciplinary (Science, Technology, Engineering, and Mathematics) STEM education that motivates students to study about the universal globe throughout examination, investigation, and problem solving practices [11]. Consequently, many improvement initiatives have formed teaching and learning STEM disciplines. These improvement efforts comprise a move fromplain instruction lessons and carry out secluded data and skills, to allowing students to practice knowledge as scientists, engineers and mathematicians [12].

"[Science] is more than a school subject, or the periodic table, or the properties of waves. It is an approach to the world, a critical way to understand and explore and engage with the world, and then have the capacity to change that world..."

- Former President Barack Obama [13]

The United Arab Emirates (UAE) is currently undergoing rapid expansion, with the Emirati government fuelling growth by investing the proceeds of high oil prices and international investments into a vast array of public and public-private enterprises. Recognizing that this increase in available funds is not in itself a long-term growth strategy, the UAE government has made a number of public commitments to strengthen the country's macroeconomic foundations, reform its regulatory environment, invest in human capital and sustain the rapid growth of the non-oil sector. A major challenge for the UAE's future is to accelerate the reform process and ensure that implementation can effectively transform the economy into one that benefits its citizens by providing abundant job opportunities in a stable and diversified growth environment. As significant shifts in oil prices, geopolitical developments, and national budget revisions continue to affect the investment climate across the Middle East, the UAE promises to invest on STEM fields for youth [14]. Therefore, the purpose of this study was to investigate Emirati youth's STEM career aspirations and their demographic variables. Factor-analytic procedures revealed a robust four-factor structure that contributed to the development of the following two research questions:

1- What are the main Emirati youth's STEM career aspirations?

Prof. Sufian A. Forawi is with The British University in Dubai 


\section{2- How do participants' STEM career aspirations vary regarding gender and grade?}

\section{BACKGROUND}

The United Arab Emirates (UAE) is currently undergoing rapid expansion, with the Emirati government fuelling growth by investing the proceeds of high oil prices and international investments into a vast array of public and public-private enterprises. Recognizing that this increase in available funds is not in itself a long-term growth strategy, the UAE government has made a number of public commitments to strengthen the country's macroeconomic foundations, reform its regulatory environment, invest in human capital and sustain the rapid growth of the non-oil sector. A major challenge for the UAE's future is to accelerate the reform process and ensure that implementation can effectively transform the economy into one that benefits its citizens by providing abundant job opportunities in a stable and diversified growth environment.

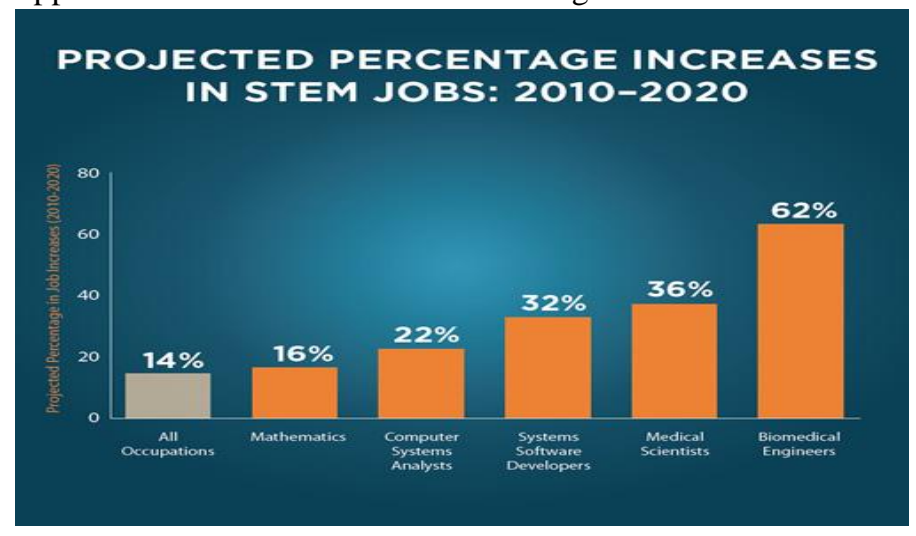

Fig. 1. Projected STEM Jobs 2020 (Vilorio, 2104)

The topic of student career aspirations is widely investigated and found to be important in many countries. Historically, the main influences seem to be personality types, the view that aspirations are a feature of an individual's psychology [15], and socio-economic factors [16]. The theory of vocational choice developed by John L. Holland is one of the most widely researched and applied theories of career development. This theory constitutes the framework of this research study. Based on the premise that personality factors underlie career choices, his theory postulates that people project self-and world-of-work views onto occupational titles and make career decisions that satisfy their preferred personal orientations. Two of the seven assumptions of Holland that relate to the present study are that (1) most people possess one of six modal personality types (RIASE): Realistic (R), Investigative (I), Artistic (A), Social (S), Enterprising (E), or Conventional (C). (2) Six modal occupational environments correspond to the six modal personality types: Realistic (R), Investigative (I), Artistic (A), Social (S), Enterprising (E), and Conventional (C). Each environment illustrates a given type of personality and physical settings posing special circumstances.
Many youths, for example in the United States, lack clear occupational aspirations. This uncertainty in achievement ambitions, as [17] continue to explain may benefit socio-economic attainment if it signifies "role exploration," characterized by career development, continued education and enduring partnerships. By contrast, uncertainty may diminish attainment if it instead leads to "aimlessness," involving prolonged education without the acquisition of a degree, residential dependence and frequent job changes. Yet, the US ensuring that all students have access to high-quality learning opportunities in STEM subjects has become a priority, demonstrated by the fact that many of federal programs have made teaching and learning in science, technology, engineering, and math a critical component of competitiveness for grant funding (e.g., Math \& Science Partnership; Race-to-the-Top; Learn TV).

Some encouragements for students to follow STEM pathways may include competition and recognition awards. The award is a communications and outreach tool to encourage state education, health, and environment authorities, stakeholders, and school communities to consider matters of facilities, health, and environment comprehensively, strengthening the critical collaborations that ensure all of our nation's schools are healthier, safer, and more sustainable. The recognition award, in US, honors public and private elementary, middle, and high schools, districts, and postsecondary institutions that are demonstrating a commitment to three Pillars: 1) reducing environmental impact and costs, including waste, water, energ y use, and alternative transportation; 2) improving the health and wellness of students and staff, including environmental health, nutrition, and fitness; and 3) providing effective sustainability education, including robust environmental education that engages STEM, civic skills, and green career pathways. Therefore, a country like the UAE should invest in such incentive and learning curve to encourage students to pursue STEM education and careers.

More recent studies have shown that socialization into the prevailing culture as well as social psychological variables are important influences on young people's educational and career aspirations [18]. In particular, [19] suggests that social class, schooling and significant others (family, friends and role models) are major constraints on young peoples' aspirations. Furthermore, gender is highly likely to significantly be related to aspirations because of the differential development of these variables in girls and boys.

\section{METHODOLOGY}

The study followed a qualitative approach with use of the Career \& Educational Aspiration Questionnaire (CEAQ) instrument, developed by Forawi (2014), that consists of five sections with 54 items. First, a demographic section is included with items on age, gender, father and mother occupations, and willingness to participate in a future follow-up interview that is not part of data presented in this study. Second, eight items on schooling, respect for teachers, and motivation for future occupation using a 4-Lakert scale, strongly agree, agree, disagree, and strongly disagree are given. The third section 
offers 28 major occupations and an open-ended item on the first preferred occupation, whether stated among the main 28 occupations or not with all the pos sibilities of 3 choices, yes, no, and not decided. In the next section, there are ten items about school and schoolwork with 4- Likert scale, strongly agree, agree, disagree, and strongly dis agree. In the final section, there are three items about the time to start working, before or after completing high school or after college and university. The CEAQ, therefore, measures different key aspects of schooling, educational and career desires along with demographic and contextual areas to allow collection of wide information on participants and their as pirations. For the purpose of this study, only some of the career related items are presented and discussed.

\section{RESULTS, DISCUSSION, \& CONCLUSION}

A large convenient nationwide sample of 5320 students from grades 8,10, and 12 included in the study. The governmental school administrators, mainly principals who delegated communication to social workers or teachers who were responsible of facilitating activities such as this, agreed to have their school participate in the study and routed the questionnaire packets to be distributed to students in all or selected classes on grades, 8, 10 and 12. The Ministry of Education, delegated to the Educational Zones in the seven Emirates in the UAE granted the permission to collect the data from selected governmental public schools, which are segregated, into boys and girls schools.

TABLE 1. RANKED ORDER OF PREFERRED TOP CAREERS

\begin{tabular}{|l|l|c|c|}
\hline$\#$ & Job & Frequency & Percentage \\
\hline 1. & Engineer & 662 & $15.90 \%$ \\
\hline 2. & Police & 603 & $14.50 \%$ \\
\hline 3. & Doctor & 493 & $11.80 \%$ \\
\hline 4. & Pilot & 351 & $8.40 \%$ \\
\hline 5. & Army, navy, air force & 316 & $7.60 \%$ \\
\hline
\end{tabular}

Table 1 above indicates the future five top job preferences by all participating students of 28 jobs stated in the CEAQ instrument in descending order. The three top jobs included two of top jobs, engineer and doctor $(15.90 \%$ \& \& $11.80 \%$, respectively), that are similar to results of previous studies. Engineering is STEM job. This result is not unusual for students at this age where interest and actual ability to achieve such interest are not correlated. However, it is interesting to know that both boys and girls at the middle and secondary levels, in the $\mathrm{UAE}$, are interested in becoming engineers, police officers and doctors. In particular, the high interest to become a police is indicated by both boys and girls as seen as a lucrative job with many benefits in the country.

By applying the paired test, to know if there is a difference in students' responses about deciding for themselves or influenced by others such as parents, family, it is found that there is significant difference between the two ideas. Students preferred to depend on themselves in selecting their future job and were open to advice from others. By introducing the gender factor in this part we found result as in table 6 below which indicated equal opinions from boys. Yet, girls showed more independence on deciding about future careers.

\section{TABLE 2}

MEANS OF OpINION ON DECIDING FUtURE JOB By GENDER

\begin{tabular}{|l|l|l|}
\hline Gender & Advice from others & Students' own thinking \\
\hline Male & 3.33 & 3.32 \\
\hline Female & 3.16 & 3.42 \\
\hline
\end{tabular}

The majority of UAE boys and girls equally decide on their own future jobs and can accept advice from others. Yet, there was not a significant difference regarding gender, Table 2, and only girls showed slightly preference on deciding for themselves when it comes to the interest in future jobs. However, in contrast, according to [9] Afro-Caribbean students found to shy away from science, and preferred to pursue degrees in the social sciences.

While most of the findings of the career as pirations are not far from those findings indicated by international research studies, the Emirati students seem to be influenced by other societal realities by indicating preference of other jobs such as police, army forces, and business, as many of their parents and others pursue such jobs. The desire of the STEM related jobs is still shay which may be affected by limited lack of awareness of such jobs, programs, and career counselling. In conclusion, as indicated by [2] that with such challenges, the Emirati youth will continue to follow step of their fathers and close role models.

\section{REFERENCES}

[1] Holubova, R. (2017). STEM Education and Fermi Problems. AIP Conference Proceedings. Vol. 1804, (pp. 1-6). https://doi.org/10.1063/1.4974372

[2] Forawi, S. A. (2014). Youth Career and Educational Aspirations: Perceptions \& Instrument Validation. International Journal of Humanities Education. 11(1), (pp. 11-25). https://doi.org/10.18848/2327-0063/CGP/v11i01/43792

[3] Schoon, I. \& Polek, E. (2011). Teenage Career Aspirations and Adult Career Attainment: The Role of Gender, Social Background and General Cognitive Ability. International Journal of Behavioral Development, 35, 3 (2011) (pp. 210-217). https://doi.org/10.1177/0165025411398183

[4] Piotrowsk, C. \& Hemasinha, R. (2012). Career Aspirations of Undergraduate Mathematics Majors: An Exploratory Study. College Student Journal, 46(1). (pp. 46-50).

[5] Judge, T. A., et al. (2009). Is Emotional Labor More Difficult for Some Than for Others? A Multilevel, Experience-sampling Study. Personnel Psychology, 62(1), (pp. 57-88). https://doi.org/10.1111/j.1744-6570.2008.01129.x

[6] Sahin, A., Oren, M., Willson, V., Hubert, T., \& Capraro, R. M. (2015). Longitudinal Analysis of T-STEM Academies: How Do Texas Inclusive STEM Academies (T-STEM) Perform in Mathematics, Science, and Reading? International Online Journal of Educational Sciences, 7(4), (pp. 11-21). https://doi.org/10.15345/iojes.2015.04.002 
[7] Bandura, A. (1989). A Social Cognitive Theory of Action. In J. P. Forgas \& M. J. Innes (Eds.), Recent Advances in Social Psychology: An International Perspective. (pp. 127-138). North Holland: Elsevier.

[8] Chantara, S., Kaewkuekool, S., \& Ravinder, K. (2011). Self Determination Theory and Career Aspirations: A Review of Literature. International Conference on Social Science and Humanity Proceedings, (pp. 212-215).

[9] Rissanen, A.J. (2014). Active and Peer Learning in STEM Education Strategy. Science Education International, 25(1) (pp. 1-7).

[10] Vilorio, D. (2014). STEM 101: Tomorrow's Jobs. Occupational Outlook Quarterly, (pp. 1-12).

[11] Bicer, A., Navruz, B., Capraro, R. M., Capraro, M. M., Oner, T. A., \& Boedeker, P. (2015). STEM schools vs. non-STEM schools: Comparing students' mathematics growth rate on high-stakes test performance. International Journal of New Trends in Education and Their Implications. 6(1), (pp.138-150).

[12] National Council of Teachers of Mathematics (NCTM). (2014). Principles to actions: Ensuring mathematical success for all. Reston, VA: NCTM.

[13] President Obama. (2015). Science, Technology, Engineering and Math: Education for Global Leadership. Retrieved on February 2017 from https://www.ed.gov/stem.

[14] MENA 2017.Beyond borders: MENA's role in the global economy. Retrieved on $\quad$ February 2017. http://middleeast investmentconference.com/Home/

[15] Holland, J. (1973). Making Vocational Choices: A Theory of Careers. Prentice-Hall, Englewood Cliffs, NJ.

[16] Crites, J. (1969). Vocational Psychology: The Study of Vocational Behavior and Development. USA, Texas: McGraw-Hill.

[17] Grunert, M., L., \& Bodner, G. M. (2011). Underneath it all: gender role identification and women chemists' career choice. Science Education International, 22(4) (pp. 292-301).

[18] Staff, J. H., at al. (2010). Uncertainty in Early Occupational Aspirations: Role Exploration or Aimlessness? Social Forces, 89,(2)(pp. 659-683).

https://doi.org/10.1353/sof.2010.0088 